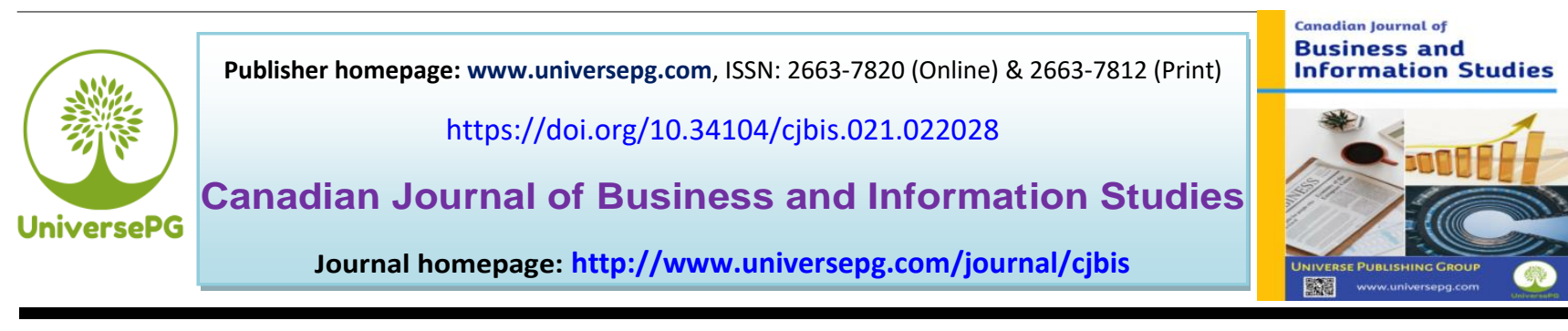

\title{
Evaluation and Analysis of User Satisfaction of Ride-Sharing Service: An Assurance and Empathy in Bangladesh Perspective
}

\author{
Tonmoy Dey ${ }^{1}$, Muhammad Abdus Salam ${ }^{1}$, and Trisha Saha ${ }^{1 *}$ \\ ${ }^{1}$ Department of Management Information Systems, Noakhali Science and Technology University (NSTU), Noakhali, \\ Bangladesh. \\ *Correspondence: trisha55mis@gmail.com (Trisha Saha, Department of Management Information Systems, NSTU, \\ Noakhali, Bangladesh.
}

\begin{abstract}
The key purpose of the research work is to evaluate and analyze ride-sharing service (RSS) users' satisfaction, from the assurance and empathy perspective in Bangladesh. Factors applied in the study are adopted from the SERVQUAL dimensions (reliability, responsiveness, assurance, tangibility, and empathy). Data were collected with a structured questionnaire from RSS users from Dhaka city. Study hypotheses were tested with the regression analysis method in SPSS. And the result indicates that ridesharing services are satisfaction generators from both the assurance and empathy perspectives. The study may provide some insights to the relevant service providers in planning further service offerings and improved services to ensure greater user satisfaction.
\end{abstract}

Keywords: Ride-sharing service, User satisfaction, Assurance, Empathy, Analysis, and Bangladesh.

\section{INTRODUCTION:}

Ride-sharing service (RSS) is a fast and emerging innovation of the $21^{\text {st }}$ century that ensures a call upon transportation service with the assistance of privately possessed vehicles typically via a mobile app supported by internet connectivity (Agatz et al., 2012). Owners can share their privately possessed vehicles with passengers, registered to a mobile app, in exchange for a fare. The conveniences of RSS have transformed the meaning of transportation system across the world. With its wide acceptance, the dependency is being reduced on private means of transportation, use of energy is being lowered, pollution of air level is being abridged, time on and costs of transportation are being cut.

RSS started to show their gig in Bangladesh with Pathao in the year of 2015 and it was an indigenous initiative (Ghosh, 2018). After that in 2016, US startup Uber started its operation in Dhaka (Ghosh, 2018). Following Pathao and Uber's commencement of operation in Bangladesh, many local companies have started their journey in the subsequent 3-4 years and currently, there are 12 registered companies (Appendix-A) in operation (BRTA, 2019).

Some companies have extended their operations to other areas in Bangladesh and other companies are also in the queue. Some significant causes, like- the gigantic population of urban areas, chaos in the traffic management system, increasing amount of mobile internet users etc., are backing up the demand for RSS in Bangladesh. All these RSS providers are competing in the marketplace with their highest potentiality and service excellence. However, some dimensions must be observed to understand the service quality of RSS and its association with the level of user satisfaction. Service quality means conformation to users' requirements as well as provider's commitment (Zeithaml et al., 1988). 
In one of our previous studies we revealed an important relationship of the service qualities of RSS with users' satisfaction level by applying five service quality dimensions (SERVQUAL model) in the context of Bangladesh (Dey et al., 2019). However, this study analyzed the user satisfaction of ridesharing services in Bangladesh from only the assurance and empathy perspectives to understand the impact of promise and compassion from the providers of this service on user satisfaction.

\section{Review of Literature}

Ride-sharing service is undoubtedly a well-accepted technology resolution to the people living in cities worldwide. A study of Ben-Dor, Ben-Elia and Benenson, (2019) reported a $20 \%$ cutback of traffic because of ride-sharing operations. However, the immense use of RSS in the well-managed city like Riyadh has augmented the total of vehicles resulting in challenges for traffic management (Chorfi et al., 2015). Safety, customer support by the service workers and service providers' concern are found as emergent issues in current time (Chaudhry et al., 2018). Hence, service excellence and user's satisfaction have become two overriding issues.

Kotler and Keller, (2016) identified pleasing status of the consumer with a desired product or service as satisfaction. While Kursunluoglu, (2011) considers that satisfaction depends how much customers' expectation could be ensured. Several researches identified that profitability of a service company depends largely on the customer portion that are satisfied and happy by the service quality (Cronin and Taylor, 1992; Shemwell et al., 1998; Zairi, 2000; Arokiasamy and Huam, 2014). Rahman, Hasan and Mia, (2017) also addressed that customer satisfaction is the result of superior service quality and it must be clear and concise in the organizations' statement. Some studies have observed the persuasion of regulation, discrimination, and accessibility in determining the connection between the user satisfaction and the service quality of RSS (Edelman and Geradin, 2015; Cramer and Krueger, 2016; Linares et al., 2017; Aarhaug and Olsen, 2018). Price, promotional activities, as well as clearance of coupon redemption are found significant in determining the RSS users' contentment of in the study of Balachandran and Hamzah, (2017). However, for evaluating the service quality of any service providers the SERVQUAL model is a broadly accepted UniversePG I www.universepg.com tool that comprises of five dimensions: reliability, responsiveness, assurance, tangibility, and empathy (Zeithaml et al., 1988). The model helps to recognize the divergence between the former and later state of service delivery. Ghosh, (2019) examined the outcome of service offering by Pathao on the users in one study and in another study, she performed a gap analysis by highlighting the expectations of RSS users and reality on the basis of SERVQUAL dimensions taking Pathao and Uber into consideration. She concludes that to ensure customer satisfaction every dimension of service quality must have to be met (Ghosh, 2018).

In contrast, Rahman et al. (2019) attempted to disclose the users' view of the service quality RSS in the context of Bangladesh. Kumar, Chun and Rahman, (2019) concluded that how the user's reception of RSS in the capital city of Bangladesh has transformed the whole structure of publicly operated transportation and came up with the insight that people are now habituated to RSS instead of transportation system that is not privately owned. Dey et al. (2019) revealed a momentous relationship between the service qualities of RSS with users' satisfaction considering five service quality dimensions (SERVQUAL model) in the context of Bangladesh. However, no direct studies have been done regarding the user satisfaction of ride-sharing services in Bangladesh from assurance and empathy perspectives. This study will explore the relationship to come up with some significant insights.

\section{Theoretical Framework and Hypothesis}

Service quality measurements model (SERVQUAL dimensions) recommended by Zeithaml et al. (1988) has been emphasized and two dimensions from its five dimensions: assurance and empathy are adopted for our research objective. They are further applied for evaluating and analyzing the link between the independent and dependent constructs. They are described below-

Assurance: It corresponds to the knowledge level, expertise and capability of the service party, safety as well as security issues in case of service delivery, and courteous behavior (Zeithaml et al., 1988).

Empathy: It corresponds to the plan of the service providers to give quality attention to the users and their capability to understand specific customer needs (Zeithaml et al., 1988). 
Based on the discussion, in the literature review section, it can be hypothesized that-

H1: Assurance has positive association with the identification of user satisfaction of RSS.

H2: Empathy has positive association with the identification of user satisfaction of RSS.

\section{METHODOLOGY:}

4.1 Questionnaire and Collection of Data - Data were collected from the RSS users of Dhaka by applying survey technique, and a controlled questionnaire was applied for that purpose. Roscoe, (1975) recommended a standard sample size not less than 30. Hence, we have collected 195 responses. Part A of the questionnaire was employed for collecting the respondent's background information. On the other hand, part B was employed for collecting data on a five-point Likert scale ranging from 1 (strongly disagree) to 5(strongly agree). Items used for measurement are provided in the Appendix B.

4.2 Method of Data Analysis - 20 unengaged data, from raw data set, was deleted using standard deviation approach and the remaining 175 data that are engaged was imported to the SPSS datasheet for further analysis. Cronbach's Alpha Reliability test was applied for checking reliability and internal consistency of the data set. Background information of the respondents was summarized using frequency and percentage. Lastly, regression analysis technique was used to test all the study hypotheses.

\section{RESULTS:}

5.1 Respondents' Background Information Referring to table $01,66.3 \%$ of the respondents are male $18-25$ is the highest age group and service holders are the highest in the portion (52.6\%). Uber is found most frequently used service amongst the available RSS of Bangladesh. Pathao is in the subsequent place of the users' choice list.

5.2 Reliability - Gliem and Gliem, (2003) stated that alpha value of 0.80 is satisfactory and should be a rational goal. Referring to table 02, Cronbach's Alpha values of all the constructs are found reliable since the values are over 0.80 .

\subsection{Hypothesis Testing}

Referring to the table $03, \mathrm{R}$ square value indicates the regression model's good enough capability to support the current study's findings as $68.4 \%$ of observed data fit the regression model.

Table 1: Background Information

\begin{tabular}{|c|c|c|c|}
\hline \multicolumn{2}{|c|}{ Variable } & \multicolumn{2}{|c|}{ Frequency/Percentage } \\
\hline \multirow[t]{3}{*}{ Gender } & Male & 116 & $66.3 \%$ \\
\hline & Female & 59 & $33.7 \%$ \\
\hline & Others & 0 & $0 \%$ \\
\hline \multirow[t]{5}{*}{ Age } & $18-27$ & 88 & $50.3 \%$ \\
\hline & $28-37$ & 49 & $28 \%$ \\
\hline & $38-47$ & 19 & $10.9 \%$ \\
\hline & $48-57$ & 16 & $9.1 \%$ \\
\hline & 58-Above & 3 & $1.7 \%$ \\
\hline \multirow[t]{5}{*}{ Profession } & Service holders & 92 & $52.6 \%$ \\
\hline & Business & 22 & $12.6 \%$ \\
\hline & Self-employed & 19 & $10.9 \%$ \\
\hline & Student & 37 & $21.1 \%$ \\
\hline & Unemployed & 5 & $2.8 \%$ \\
\hline \multirow{7}{*}{$\begin{array}{c}\text { Preference } \\
\text { of App }\end{array}$} & Pathao & 36 & $20.6 \%$ \\
\hline & PickMe & 7 & $4 \%$ \\
\hline & Buddy & 5 & $2.8 \%$ \\
\hline & Obhai & 17 & $9.7 \%$ \\
\hline & Ezzyr & 4 & $2.3 \%$ \\
\hline & Uber & 96 & $54.9 \%$ \\
\hline & Sohoz & 10 & $5.7 \%$ \\
\hline \multirow{3}{*}{$\begin{array}{l}\text { Weekly } \\
\text { Use } \\
\text { Frequency }\end{array}$} & Rarely & 29 & $16.6 \%$ \\
\hline & Frequently & 107 & $61.1 \%$ \\
\hline & Very Frequently & 39 & $22.3 \%$ \\
\hline
\end{tabular}

Table 2: Reliability Assessment

\begin{tabular}{|c|c|}
\hline Construct & Cronbach's Alpha \\
\hline Assurance & .864 \\
\hline Empathy & .875 \\
\hline User Satisfaction & .898 \\
\hline
\end{tabular}

Table 4 illustrates the $F$ value 53.165 with an associated $p$ value (significance) less than 0.05 and it shows that the independent variables' significant impact on dependent variable. From table 05 , p value of assurance factor and empathy factor can be retrieved and they are 0.000 and 0.003 respectively. It indicates that both of the factors are positively correlated with the satisfaction aspect of RSS users. Hence, null hypotheses are rejected and $\mathrm{H} 1$ and $\mathrm{H} 2$ hypotheses are accepted:

H1: Assurance has positive association with the identification of user satisfaction of RSS.

H2: Empathy has positive association with the identification of user satisfaction of RSS. 
Table 03: Regression Model Summary

\begin{tabular}{|c|c|c|c|c|}
\hline Model & R & R Square & Adjusted R Square & Std. Error of the Estimate \\
\hline 1 & $.827^{\mathrm{a}}$ & .684 & .678 & .15421 \\
\hline
\end{tabular}

Table 04: ANOVA

\begin{tabular}{|l|l|c|c|c|c|c|}
\hline \multicolumn{2}{|l|}{ Model } & Sum of Squares & Df & Mean Square & F Statistics & Sig. \\
\hline 1 & Regression & 42.426 & 2 & 21.213 & 53.165 & $.000^{\mathrm{a}}$ \\
\hline & Residual & 68.664 & 172 & 0.399 & & \\
\hline & Total & 111.09 & 174 & & & \\
\hline
\end{tabular}

Table 05: Coefficients

\begin{tabular}{|l|l|c|c|c|c|c|}
\hline \multicolumn{2}{|l|}{ Model } & Unstandardized Coefficients & Standardized Coefficients & \multirow{2}{*}{ t } & \multirow{2}{*}{ Sig. } \\
\cline { 3 - 8 } \multicolumn{2}{|l|}{1} & B & Std. Error & Beta & & \\
\hline & (Constant) & 1.542 & .314 & & 3.452 & .000 \\
\cline { 2 - 8 } & Assurance & .661 & .063 & .663 & 7.027 & .000 \\
\cline { 2 - 8 } & Empathy & .626 & .068 & .624 & 8.112 & .003 \\
\hline
\end{tabular}

\section{DISCUSSION:}

We found both the hypotheses ( $\mathrm{H} 1$ and $\mathrm{H} 2)$ accepted which indicates significant influences of both the assurance dimension and empathy dimension on the identification of user satisfaction of RSS in Bangladesh. Users are confident enough to use RSS frequently as they find the service safe and reliable. Moreover, they are convinced with the professionalism, skill and knowledge level of the riders regarding the driving manner, traffic rules, and regulations. Although, there are some reports in recent times regarding a few criminal activities that can be observed in which riders were found guilty. However, those open and shut cases are now lessening as the party providing RSS services have revised riders' policy and the authorities engaged in the legal administration are now highly concerned about the safety of the users.

Furthermore, users are found satisfied also because they believe that the RSS providers work for delivering the highest value towards them. RSS now are convenient for females, kids, and also for the physically challenged people. Moreover, 24×7 facilities of RSS is one of the reasons behind RSS's acceptance. However, a few respondents reported some unprofessionalism cases of the riders and service providers; complained about their manner, punctuality, unwillingness to receive digital money, and customer support. These percentages are few in number. Yet, these findings need to be considered by the service providing party for the betterment in delivery quality service.

\section{CONCLUSION:}

RSS, a widely accepted IT-enabled service, is constantly transforming the overall traffic and transportation systems of Bangladesh particularly in city areas. It has turned into a demand of time and no longer remained a luxury in everyday life. People staying at city areas are always in trouble with time and cost issues of transportation. Besides, air and sound pollution are also causing health issues. Government and related authorities are also facing challenges to regulate the current situation of urban areas' traffic controlling systems. It becomes a harsh reality that Bangladesh is a densely populated country and often economically challenged. Most of its people want to secure a minimum standard of living, and that made urban areas more densely populated. All these challenges have created the need for sound transportation and traffic systems. Ride-sharing service is surely a potential solution to this problem. As RSS is getting bigger and popular gradually, the most challenging issue is now the demand for their providers' service quality. In our study, we have attempted to find out the satisfaction level of RSS users' from the perspective of assurance and empathy factors and in conclusion, we found both service quality dimensions (assurance and empathy) are significant in generating expected service excellence and they are influential to the users' contentment. It may provide insight to the party providing RSS services that how users perceive and value them, what their expectations are etc. Therefore, the service providers must maintain the consistency of 
their commitment and compassion in delivering services. It will assist to capture and retain more market shares. New companies should consider these insights if they want to capture a share in the market fast.

\section{LIMITATIONS AND FUTURE SCOPE:}

This study has only considered the two factors among the five service quality dimensions SERVQUAL model in exploring users' satisfaction. Other dimensions must be taken into considerations in future studies. Besides, some social, cultural, economic issues must be taken into considerations as moderating factors in future studies, which can justify the satisfaction level of users' more critically. Moreover, we have collected data were only from the Dhaka city's people. Hence, other areas where RSS are in operation can be taken into considerations by the future researches.

\section{ACKNOWLEDGEMENT:}

We would like to express our gratitude towards the respondents, the officials of Bangladesh Road Transportation Authority (BRTA), and PRs of Ride-sharing service providers for their enormous support and responses for making our investigation complete.

\section{CONFLICTS OF INTEREST:}

We declare no single potential conflict of interest.

\section{REFERENCES:}

1) Aarhaug, J. and Olsen, S. (2018). 'Implications of ride-sourcing and self-driving vehicles on the need for regulation in unscheduled passenger transport', Research in Transportation Economics, 69, pp. 573582.

https://doi.org/10.1016/j.retrec.2018.07.026

2) Agatz, N. et al. (2012). 'Optimization for dynamic ride-sharing: A review', European J. of Operational Res., 223(2), pp. 295-303. https://doi.org/10.1016/j.ejor.2012.05.028

3) Arokiasamy, A. R. A. and Huam, H. T. (2014). 'Assessing the relationship between service quality and customer satisfaction in the Malaysian automotive insurance industry', Middle-East J. of Scientific Research. 20(9), pp. 1023-1030.

http://library.oum.edu.my/repository/id/eprint/ $\underline{943}$

4) Balachandran, I. and Hamzah, I. Bin (2017). 'The influence of customer satisfaction on ride-sharing services in Malaysia', International J. of Accounting and Business
Management, 5(2), pp. 184-196. http://www.ejournal.aibpm.org/index.php/IJT HAP/article/download/820/782

5) Ben-Dor, G., Ben-Elia, E. and Benenson, I. (2019). 'Determining an optimal fleet size for a reliable shared automated vehicle ridesharing service', Procedia Computer Science, 151, pp. 878-883.

https://doi.org/10.1016/j.procs.2019.04.121

6) BRTA, (2019). List of Ride Sharing Companies, www.brta.gov.bd. Available at: http://brta.portal.gov.bd/sites/default/files/files /brta.portal.gov.bd/page/1758a94f_5ca7_40bc aale a00bc47dbc6b/List of approved Ride sharing Companies.pdf

7) Butt, M. M. and de Run, E. C. (2010). 'Private healthcare quality: applying a SERVQUAL model', International $j$. of health care quality assurance. 23(7), pp. 658-673.

https://doi.org/10.1108/09526861011071580

8) Chaudhry, B. et al. (2018). 'Passenger safety in ride-sharing services', Procedia computer science, 130, pp. 1044-1050.

https://doi.org/10.1016/j.procs.2018.04.146

9) Chorfi, H. et al. (2015). 'A smart real-time ride-share for Riyadh city', Procedia-Social and Behavioral Sci.. 195, pp. 1932-1937. https://doi.org/10.1016/j.sbspro.2015.06.205

10) Cramer, J. and Krueger, A. B. (2016). 'Disruptive change in the taxi business: The case of Uber', American Economic Review, 106(5), pp. 177-182.

https://www.aeaweb.org/articles/pdf/doi/10.12 57/aer.p20161002

11) Cronin Jr, J. J. and Taylor, S. A. (1992). 'Measuring service quality: a reexamination and extension', Journal of marketing, 56(3), pp. 55-68.

https://doi.org/10.1177/002224299205600304

12) Dey, T. et al. (2019). 'Relationship between service quality and user satisfaction: An analysis of ride-sharing services in Bangladesh based on SERVQUAL dimensions', Journal of Noakhali Science and Technology University (JNSTU), 3(1), pp. 37-47.

https://journal.nstu.edu.bd/index.php/sj/article/ view/9

13) Edelman, B. G. and Geradin, D. (2015). 'Efficiencies and regulatory shortcuts: How should we regulate companies like Airbnb and Uber', Stan. Tech. L. Rev. HeinOnline, 19, pp. 293-328.

https://dx.doi.org/10.2139/ssrn.2658603

14) Ghosh, M. (2018). 'Customers' Expectations Meet Perceptions or Not: App-Based RideSharing Services by Uber and Pathao in 
Dhaka City.', ASA University Review, 12(2), pp. 29-50.

http://www.asaub.edu.bd/asaubreview/data/v1 2n2/v12n3.pdf

15) Ghosh, M. (2019). 'Service Offerings, Performance Measurement and Performance Indicators of Pathao Rides in Dhaka city', in The Proceedings of the $2^{\text {nd }}$ Inter-national Conference on Business and Mana-gement (ICBM 2019). Dhaka: BRAC Busi-ness School, pp. 88-90.

https://www.researchgate.net/publication/3499 $\underline{66100}$

16) Gliem, J. A. and Gliem, R. R. (2003). 'Calculating, interpreting, and reporting Cronbach's alpha reliability coefficient for Likert type scales', in, pp. 82-88. http://hdl.handle.net/1805/344

17) Koivumäki, T., Ristola, A. and Kesti, M. (2008). 'The effects of information quality of mobile information services on user satisfaction and service acceptance empirical evidence from Finland', Behaviour \& Information Technology, 27(5), 375-385. https://doi.org/10.1080/01449290601177003

18) Kotler, P. T. and Keller, K. L. (2016). Marketing Management: Global Edition. $15^{\text {th }}$ edn. Pearson.

19) Kumar, R., Chun, Y. and Rahman, A. (2019) 'The impacts of ride-sharing on traditional transportation sectors:"A case study of Dhaka, Bangladesh".', IOSR Journal of Business and Management, 21(5), 16-25. https://www.iosrjournals.org/iosr-jbm/papers/ Vol21-issue5/Series-10/C2105101625.pdf

20) Kursunluoglu, E. (2011). 'Customer service effects on customer satisfaction and customer loyalty: A field research in shopping centers in Izmir City-Turkey', International $J$. of business and social science. 2(17), pp. 52-59.

https://ijbssnet.com/journal/index/649:vol-2no-17abstract8\&catid=19:hidden

21) Linares, M. P. et al. (2017). 'Analysis and operational challenges of dynamic ride sharing demand responsive transportation models', Transportation Research Procedia. 21, pp. 110-129. https://doi.org/10.1016/j.trpro.2017.03.082

22) Mikhaylov, A. S., Gumenuk, I. S. and Mikhaylova, A. A. (2015). 'The SERVQUAL model in measuring service quality of public transportation: evidence from Russia',
Calitatea. Romanian Society for Quality Assurance, 16(144), pp. 78-83.

https://www.researchgate.net/publication/2748 35389

23) Muthupandian, K. S. and Vijayakumar, D. C. (2012). 'Measurement of passengers service quality in public transportation: servqual analysis', Business Plus, 1(5), pp. 1-9. https://mpra.ub.uni-muenchen.de/id/eprint/3 $\underline{8584}$

24) Ojo, T. K. et al. (2014). 'Service quality and customer satisfaction of public transport on Cape Coast-Accra Route, Ghana', Developing Country Studies, 4(18), pp. 142-149. https://www.researchgate.net/publication/2663 85664

25) Rahman, A., Hasan, M. and Mia, M. A. (2017). 'Mobile banking service quality and customer satisfaction in Bangladesh: An analysis', The Cost and Management, 45(2), pp. 25-32.

26) Rahman, F., Islam, M. A. U. and Hasan, M. M. (2019). Exploring Passengers Perception of ride sharing service on Dhaka city, in and Practice (iCERP2019) $4^{\text {th }}$ GCSTMR World Congress. Dhaka: Science, Techno-logy and Management Crest, pp. 36-46.

https://www.researchgate.net/profile/Qingtao Huang2/publication/334081834

27) Roscoe, J. T. (1975). Fundamental Research Statistics for the Behavioral Sciences. $2^{\text {nd }}$, illustr edn. New York: Holt, Rinehart and Winston.

28) Shemwell, D. J., Yavas, U. and Bilgin, Z. (1998). 'Customer-service provider relationships: an empirical test of a model of service quality, satisfaction and relationship-oriented outcomes', International J.of Service Industry Management. 9(2), pp. 155-168. https://www.researchgate.net/publication/2353 10840

29) Zairi, M. (2000). 'Managing customer dissatisfaction through effective complaints management systems', The TQM magazine. 12(5), pp. 331-337. https://doi.org/10.1108/09544780010341932

30) Zeithaml, V. A., Berry, L. L. and Parasuraman, A. (1988). 'Communication and control processes in the delivery of service quality', Journal of marketing. 52(2), pp. 35-48.

https://doi.org/10.2307/1251263 


\section{APPENDIX}

A. BRTA approved RSS providers in Bangladesh

\begin{tabular}{|l|l|c|}
\hline SL. & \multicolumn{1}{|c|}{ Company Name } & Source \\
\hline 01 & PickMe Ltd. & \\
\hline 02 & Computer Network System Ltd. & (BRTA, 2019) \\
\hline 03 & Obhai Solutions Ltd. & \\
\hline 04 & Chaldal Ltd. & \\
\hline 06 & Pathao Ltd. & \\
\hline 07 & Ezzyr Technologies Ltd. & \\
\hline 08 & Sejesto Ltd. & \\
\hline 10 & Sohoz Ltd. & \\
\hline 11 & Bber Bangladesh Ltd. & \\
\hline 12 & Akij Online Limited & \\
\hline
\end{tabular}

B. Measurement Items used in the Questionnaire

\begin{tabular}{|c|c|c|c|}
\hline Constructs & & Items & Sources \\
\hline \multirow[t]{3}{*}{ Assurance } & AS1 & It is safe to use RSS. & \multirow{9}{*}{$\begin{array}{l}\text { (Koivumäki et al., 2008; Butt and de Run, } \\
\text { 2010; Muthupandian and Vijayakumar, } \\
\text { 2012; Ojo et al., 2014; Mikhaylov et al., } \\
\text { 2015) }\end{array}$} \\
\hline & AS2 & $\begin{array}{l}\text { Drivers are skilled and aware of traffic rules } \\
\text { and regulations. }\end{array}$ & \\
\hline & AS3 & I feel confident for choosing RSS. & \\
\hline \multirow[t]{3}{*}{ Empathy } & EM1 & $\begin{array}{l}\text { RSS providers value the best attention of } \\
\text { their users. }\end{array}$ & \\
\hline & EM2 & $\begin{array}{l}\text { Females, kids, and the physically } \\
\text { challenged persons are especially valued by } \\
\text { service providers. }\end{array}$ & \\
\hline & EM3 & RSS is convenient in relations to time. & \\
\hline \multirow{3}{*}{$\begin{array}{c}\text { User } \\
\text { Satisfaction }\end{array}$} & US1 & RSS is a satisfying experience. & \\
\hline & US2 & I prefer the service usages. & \\
\hline & US3 & I am contented with the RSS usages. & \\
\hline
\end{tabular}

Citation: Dey T, Salam MA, and Saha T. (2021). Evaluation and analysis of user satisfaction of ridesharing service: an assurance and empathy in Bangladesh perspective, Can. J. Bus. Inf. Stud., 3(2), 22-28. https://doi.org/10.34104/cjbis.021.022028 